\title{
Serum parathyroid hormone is related to genetic variation in vitamin $D$ binding protein with respect to total, free, and bioavailable 25 -hydroxyvitamin $D$ in middle-aged Caucasians - a cross-sectional study
}

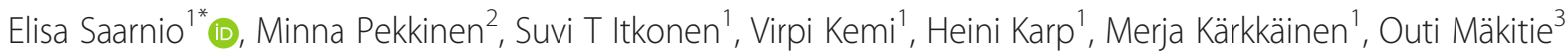
and Christel Lamberg-Allardt ${ }^{1}$

\begin{abstract}
Background: Vitamin D binding protein (DBP) binds vitamin D and its plasma metabolites, including 25hydroxyvitamin $\mathrm{D}(25(\mathrm{OH}) \mathrm{D})$, in the circulation. Only a small fraction circulates free (free $25(\mathrm{OH}) \mathrm{D})$. Genetic variation of the GC gene, encoding DBP, has been associated with 25(OH)D concentrations. The roles of DBP and free $25(\mathrm{OH})$ $D$ concentrations in the biological actions of vitamin $D$ remain unclear.

Methods: We assessed the relationship between GC gene variants rs4588, rs7041, and rs705124, and serum total $25(\mathrm{OH}) \mathrm{D}$, free and bioavailable 25(OH)D, and serum DBP and parathyroid hormone $(\mathrm{PTH})$ concentrations in 622 Caucasian females (421) and males (201) aged 37-47 years. Concentrations of 25(OH)D, DBP, and PTH were measured from fasting blood samples. Dietary intakes of vitamin D and Ca were evaluated using 1-month food use frequency data, which were collected by a validated Food Frequency Questionnaire on vitamin D and calcium intakes. The subjects filled in the questionnaire covering overall health, medications, use of vitamin D and calcium supplements, and holidays in sunny locations. Three SNPs in the GC gene were genotyped: rs4588, rs7041, and rs705124. The SNPs rs4588 and rs7041 combine to form six common diplotypes. Free and bioavailable 25(OH)D were calculated by using specific binding coefficients. Differences among the diplo- and haplotypes of the GC gene in measures of 25(OH)D, DBP, and PTH were tested by analysis of covariance (ANCOVA) using appropriate covariates.

(Continued on next page)
\end{abstract}

\footnotetext{
* Correspondence: elisa.saarnio@helsinki.fi

${ }^{1}$ Calcium Research Unit, Department of Food and Environmental Sciences,

University of Helsinki, P.O. Box 66FI-00014 Helsinki, Finland

Full list of author information is available at the end of the article
} 
(Continued from previous page)

Results: We found significant variation among the SNPs rs4588 and rs7041 variants in DBP, total, free, and bioavailable $25(\mathrm{OH}) \mathrm{D}$, and PTH. DBP concentration was lowest in genotype GC2/2 in both diplotypes and haplotypes ( $p=0.039$ and 0.039 , respectively). The lowest $25(\mathrm{OH}) \mathrm{D}$ concentrations were found in diplotype variants GC1S/2, GC1S/F, and GC2/2 ( $p=0.033)$, but free and bioavailable $25(\mathrm{OH}) \mathrm{D}$ concentrations were highest in the GC2/2 variant after corrected with a genotype-specific binding coefficient ( $p<0.001$ in both groups). Surprisingly, one of the lowest PTH concentrations was also present in variant GC2/2 in diplotypes ( $p=0.040$ of the overall ANCOVA analysis of PTH). Among SNP rs705124, there was a difference only in PTH concentrations $(p=0.013)$.

Conclusions: Our findings indicate that genetic variation of the DBP coding gene, and free concentrations of $25(\mathrm{OH}) \mathrm{D}$ may be relevant when vitamin D status, metabolism, and action are investigated.

Keywords: Vitamin D binding protein, PTH, 25(OH)D, Free 25(OH)

\section{Background}

Vitamin D, obtained from the diet or produced from 7dehydrocholesterol in the skin during UVB-exposure, is hydroxylated into prohormone 25-hydroxyvitamin D $(25(\mathrm{OH}) \mathrm{D})$ in the liver. Serum $25(\mathrm{OH}) \mathrm{D}$ is the biomarker most commonly used for describing vitamin $\mathrm{D}$ status. The active metabolite, 1,25-dihydroxyvitamin D $\left(1,25(\mathrm{OH})_{2} \mathrm{D}_{3}\right)$, is produced in the kidneys and probably also in several other tissues, and has an important role in regulating calcium homeostasis and skeletal mineral balance as well as having roles in many other physiological systems. Vitamin D binding protein (DBP) transports $25(\mathrm{OH}) \mathrm{D}$ from the liver to the kidneys and other tissues. DBP binds $85-90 \%$ of the total circulating $25(\mathrm{OH}) \mathrm{D}$ and $85 \%$ of the total circulating $1,25(\mathrm{OH})_{2} \mathrm{D}_{3}$. Albumin and lipoproteins bind the remaining $15 \%$, but with a lower affinity. Less than $1 \%$ of the vitamin D metabolites are free in circulation [1]. In addition to being a transport protein, DBP is suggested to have a role in bone formation. In its deglycosylated form, DBP can act as a macrophage activating factor and produce morphological changes in osteoclasts and also activate them, which is correlated with enhanced bone resorption [2-4]. The DBP coding gene, $G C$ gene, has two well-known missense variations in exon 11: a $G>A$ substitution, which results in p.T416K, and a $\mathrm{C}>\mathrm{A}$ substitution, which results in T420K, leading to a Threonine/Lysine amino acid change [5]. Haplotypes of the nucleotide changes result in the protein isoforms GC1S, GC2, and GC1F. Thus, the two gene variants, rs4588 and rs7041, in general combine to form six diplotypes: GC1S/1S, GC1S/2, GC1F/1 F, $G C 1 F / 2, G C 1 F / 1 S$, and $G C 2 / 2[6,7]$.

The free hormone hypothesis states that only hormones not bound to binding protein can enter the cells and have actions there [8]. Because the affinity of albu$\min$ to $25(\mathrm{OH}) \mathrm{D}$ is very weak, the bioavailable $25(\mathrm{OH}) \mathrm{D}$ represents the sum of free and albumin bound fraction of $25(\mathrm{OH}) \mathrm{D}$. S25 $(\mathrm{OH}) \mathrm{D}$ is commonly known to enter the cells in a $25(\mathrm{OH}) \mathrm{D}-\mathrm{DBP}$ complex via a megalin- mediated receptor. However, many tissues, especially extra-renal tissues, do not express megalin, and in these cases unbound free or bioavailable $25(\mathrm{OH}) \mathrm{D}$ might be the form in which vitamin $\mathrm{D}$ enters the cells. Thus, these metabolites have been suggested to be better markers of vitamin D status/concentrations [9-11].

Several studies have reported an association between $G C$ genetic variation and serum $25(\mathrm{OH}) \mathrm{D}$ concentrations. There is also evidence that DBP concentration and affinity to $25(\mathrm{OH}) \mathrm{D}$ varies between the $G C$ genotypes, and this variation may be of importance when serum $25(\mathrm{OH}) \mathrm{D}$ concentrations are interpreted [6]. It is currently unclear whether the variation in DBP concentration results in a change in biologically available 25(OH)D (free 25(OH)D) [12].

PTH is a key regulator of calcium balance in the body, and it correlates inversely with $25(\mathrm{OH}) \mathrm{D}$. Increased concentrations of PTH affect bone negatively [13]. We hypothesized that free and bioavailable $25(\mathrm{OH}) \mathrm{D}$ as well as the genetic variation in the DBP could affect these associations. The aim of this study was to examine the association between $G C$ genotypes, DBP, serum total, free, and bioavailable $25(\mathrm{OH}) \mathrm{D}$, and $\mathrm{PTH}$ concentration in an adult Caucasian population.

\section{Methods}

\section{Study subjects and study design}

The data for this study originates from the "Dietary phosphorus and health outcomes (PHOMI) study", a crosssectional study of 653 individuals of Caucasian background aged $37-47$ years living in the Helsinki area $\left(60^{\circ} \mathrm{N}\right.$, southern Finland) who were derived from the Population Register Center. The study design and methods are described in detail in Itkonen et al. [14]. The final number of the subjects was intended to be 800 persons in the original study (400 females and 400 males). The number is based on a power of $80 \%(\alpha=0.05)$ to find a $4 \%$ difference (standard deviation, SD-0.050 g/ $/ \mathrm{cm}^{2}$ ) in distal radius bone mineral density between the highest and lowest phosphorus intake 
tertiles (data not shown), and taking into account the initial dropout of $40 \%$ (based on 1200 subjects).

The initial exclusion criterion was pregnancy. Subjects visited the research unit two times during spring 2010: on the first visit (January or March), fasting blood samples and spot urine samples were collected and subjects were advised to fill in the study form, which included a food frequency questionnaire (FFQ) concerning vitamin $\mathrm{D}$ and calcium (Ca) intake, and a background questionnaire. All forms were checked by the researchers, and additional information was requested if needed. Due to missing data (e.g. background, blood sample, or genotype), the total number of subjects was 622 (421 women and 201 men). Morbidly obese (BMI $\geq 40)$ and chronically ill individuals were excluded from the analysis.

\section{Dietary intake and background data collection}

The dietary intakes of vitamin D and Ca during the preceding month were evaluated using a validated FFQ covering over 70 foods [15]. The subjects completed a questionnaire on medical history, medications and overall health, use of vitamin D and Ca supplements, and details about their physical activity. The average physical activity was measured in minutes per week and included all reported supervised and unsupervised exercise as well as functional exercise. Holidays spent in sunny locations during winter 2009-2010, from November 2009 to January 2010 (group 1) or from November 2009 to March 2010 (group 2), served as a measure of sunshine exposure. Sunny locations were defined as locations with a possibility for exposure to UV-irradiation. The persons who used sunbed over ten times during 2008-2010 were excluded from the analysis $(N=14)$.

\section{Genotype analysis of the GC gene}

SNPs covering the DBP gene region were selected from the International HapMap Project database. The data is available in International database 1000 Genomes Browser (http://www.ncbi.nlm.nih.gov/variation/tools/ 1000 genomes/). We used the function "Download tag SNP data" and selected three polymorphisms as representative of the polymorphisms in the DBP gene region. These were polymorphisms that represented the linkage disequilibrium structure of a region. Preference was given to polymorphisms with high heterozygosity levels and SNPs that are functional and have previously shown association in other studies. CEU population was used as a reference when selecting these three SNPs.

The selected SNPs were genotyped by using TaqMan chemistry on an automatic sequence-detection instrument (ABI Prism 7900HT, Applied Biosystems, Foster City, CA, USA) according to the manufacturer's protocol. Assays and reagents were supplied by Applied Biosystems. Genotypes were analyzed with SDS 2.3 and haplotypes with
HaploView 4.2. The following SNPs were genotyped: rs4588 (Taqman SNP Assay ID: C__8278879_10), rs7041 (Taqman SNP Assay ID: C__3133594_30), and rs705124 (Taqman SNP Assay ID: C__8278822_10).

\section{DBP analysis}

DBP was isolated from plasma samples and protein concentrations were determined with a commercially available ELISA assay (Immundiagnostik AG, Bensheim, Germany). This method uses polyclonal DBP antibodies.

\section{Biochemistry}

Twelve-hour fasting blood samples were collected on the first visit. All samples were obtained between 7:30 and 9:15 a.m., and serum was extracted from blood by centrifugation (except for whole-blood samples for DNA isolation) and stored immediately after sampling at $-20^{\circ}$ $\mathrm{C}$ to $-70{ }^{\circ} \mathrm{C}$ to await analysis. Serum $\mathrm{Ca}$, albumin, and creatinine were analyzed by a photometric method by using a Konelab20 automatic analyzer (Thermo Clinical Labsystems, Espoo, Finland). Inter and intra CV\%s were $<4.6$ for the above-mentioned analyses. S-25(OH)D concentrations were analyzed by using an IDS enzyme immunoassay kit (Immunodiagnostics Systems Ltd., Boldon, UK). Inter and intra CV\%s were 2.7 and 3.2, respectively. Serum PTH concentrations were analyzed by using an immunoluminescence-based method (Immulite1000, Siemens Healthcare Diagnostics, NY, USA). Inter $\mathrm{CV} \%$ was 8.0 and intra $\mathrm{CV} \%<5.5$.

\section{Calculation of free and bioavailable 25(OH)D}

Calculation of free $25(\mathrm{OH}) \mathrm{D}$ was performed using the following equation $[1,11]$ :

$$
[F]=\frac{[\mathrm{T}]}{(1+\mathrm{KALB}[\mathrm{ALB}]+\mathrm{KDBP}[\mathrm{DBP}])}
$$

Where $\mathrm{T}$ and $\mathrm{F}$ are the total and free vitamin $\mathrm{D}$ concentrations, respectively, and KALB and KDBP are the affinity constants for 25(OH)D with albumin and DBP. When the diplotype- and haplotype-corrected free and bioavailable $25(\mathrm{OH}) \mathrm{D}$ values were calculated, the affinity constants of $25(\mathrm{OH}) \mathrm{D}$ with albumin and DBP were replaced with the genotype-specific affinity constants.

The affinity constant used for albumin was $6 \times 10^{5}$ and for DBP $7 \times 10^{8}$. Haplotype-corrected free $25(\mathrm{OH}) \mathrm{D}$ concentration was calculated by placing a haplotypespecific affinity constant in the formula by Arnaud et al. [6]. Diplotype-corrected free 25(OH)D concentrations were calculated based on the affinity constants for GC1S, GC1F, and GC2. The binding coefficients of the diplotypes were calculated as the mean of the corresponding two haplotypes according to Johnsen et al. [10]. The diplotype-corrected affinity constants were as 
follows: $1 \mathrm{~S} / 1 \mathrm{~S}=6 \times 10^{8}, 1 \mathrm{~S} / 2=4.8 \times 10^{8}, 1 \mathrm{~F} 1 \mathrm{~F}=11.2 \times$ $10^{8}, 1 \mathrm{~F} / 1 \mathrm{~S}=8.6 \times 10^{8}, 1 \mathrm{~F} / 2=7.4 \times 10^{8}$ and $2 / 2=3.6+$ $10^{8}$. Bioavailable $25(\mathrm{OH}) \mathrm{D}$ and the haplotype/diplotypecorrected bioavailable $25(\mathrm{OH}) \mathrm{D}$ were calculated as a sum of free $25(\mathrm{OH}) \mathrm{D}$ and albumin-bound $25(\mathrm{OH}) \mathrm{D}$.

\section{Statistical analyses}

Descriptive data are reported as means \pm SD. We used a Chi-square test to assess whether DBP genotype distributions were in Hardy-Weinberg equilibrium. Associations between variables of interest were tested with the Pearson correlation. Logarithmic transformation was applied to non-Gaussian variables. If outliers were detected, Spearman correlation was used instead. ANCOVA analysis was used to test variation among the GC genotypes in serum total, free, bioavailable, and genotype-corrected 25(OH)D concentrations. Vitamin D intake, S-PTH concentration, holidays in sunny locations, sex and BMI was used as covariates. ANCOVA analysis was also applied to test the variation between the $G C$ genotypes and DBP as well as between the $G C$ genotypes and PTH. In the DBP analysis, sex and BMI were used as covariates and in the PTH analysis, $25(\mathrm{OH}) \mathrm{D}$ and $\mathrm{Ca}$ intake were the covariates. Tests for linear trend among the genotypes in the $25(\mathrm{OH}) \mathrm{D}, \mathrm{PTH}$, and DBP concentrations were performed by using contrast analysis. In this analysis, the three genotypes of the SNP 4588 were coded as $-1,0$, and 1 .

All calculations were performed using PASW Statistics version 18.0.2 (IBM, Armonk, NY, USA). A $p$-value of less than 0.05 was considered significant.

\section{Results}

\section{Characteristics of participants}

The background characteristics of all subjects are presented in Table 1. Background characteristics stratified by genotypes are presented in Additional file 1: Table S1. Women and men differed significantly in height, weight, BMI, history of smoking, serum albumin concentrations, and amount of physical activity (Additional file 2: Table S2).

The mean total vitamin D intake was $15.1 \mu \mathrm{g} / \mathrm{d}$, and intake from supplements was $7.2 \mu \mathrm{g} / \mathrm{d}$. No significant difference was present in vitamin $\mathrm{D}$ intake among the genotypes. The mean Ca intake was $1253 \mathrm{mg} / \mathrm{d}$ and intake from supplements $87 \mathrm{mg} / \mathrm{d}$. The mean daily vitamin $\mathrm{D}$ and $\mathrm{Ca}$ intakes (including supplements) were in line with Nordic recommendations for vitamin D and Ca intake [16].

The mean serum $25(\mathrm{OH}) \mathrm{D}$ concentration in the total population was $56 \mathrm{nmol} / \mathrm{L}$ and the mean serum $\mathrm{PTH}$ concentration $54.6( \pm 25) \mathrm{ng} / \mathrm{L}$. The mean DBP concentration was $368( \pm 88) \mathrm{mg} / \mathrm{L}$. No significant correlation was found between the $25(\mathrm{OH}) \mathrm{D}$ concentrations and the DBP concentrations $(r=-0.018, p=0.678)$. A negative correlation was present between S-PTH and total
Table 1 Characteristics of all subjects

\begin{tabular}{|c|c|c|c|}
\hline Variable & $N=622$ & & \\
\hline Men (\%) & 32 & & \\
\hline Women (\%) & 68 & & \\
\hline Age (years) & 42 & \pm & 3 \\
\hline Height (cm) & 1.70 & \pm & 0.1 \\
\hline Weight (kg) & 76 & \pm & 14 \\
\hline Body mass index $\left(\mathrm{kg} / \mathrm{m}^{2}\right)$ & 26.2 & \pm & 4.3 \\
\hline Calcium intake (mg/day) & 1253 & \pm & 530 \\
\hline Vitamin D intake $(\mu \mathrm{g})$ & 15.1 & \pm & 13 \\
\hline $\mathrm{S}-25(\mathrm{OH}) \mathrm{D}(\mathrm{nmol} / \mathrm{L})$ & 55.7 & \pm & 19.2 \\
\hline Free $25(\mathrm{OH}) \mathrm{D}(\mathrm{pmol} / \mathrm{L})$ & 12.2 & \pm & 4.9 \\
\hline Bioavailable 25(OH)D (nmol/L) & 4.80 & \pm & 2.0 \\
\hline S-PTH (ng/L) & 54.6 & \pm & 25 \\
\hline $\mathrm{S}-\mathrm{DBP}(\mathrm{mg} / \mathrm{L})$ & 368 & \pm & 88 \\
\hline S-Albumin (g/L) & 43.7 & \pm & 3.0 \\
\hline All physical activity (min/week) & 481 & \pm & 372 \\
\hline History of regular smoking ${ }^{a}(\%)$ & 46 & & \\
\hline \multicolumn{4}{|l|}{ Current Smokers: } \\
\hline \multicolumn{4}{|l|}{ Cigarettes per day } \\
\hline $1-5$ & $17 \%$ & & \\
\hline 6 or more & $83 \%$ & & \\
\hline
\end{tabular}

Values are presented as mean $\pm \mathrm{SD}$

at least one cigarette per day for 6 months

25(OH)D $(r=-0.235, p<0.001)$. Similar negative correlations were also observed between free and bioavailable $25(\mathrm{OH}) \mathrm{D}$ and S-PTH $(r=-0.223, p<0.001 ; r=-0.217$, $p<0.001)$. Total $25(\mathrm{OH}) \mathrm{D}$ correlated negatively with BMI $(r=-0.173, p<0.001)$.

\section{Genotype, haplotype, and allele distributions}

The distribution of the $G C$ genotypes was as follows: $64 \% G C 1 / 1,31.5 \% G C 1 / 2$, and $4.5 \% G C 2 / 2$. When the SNPs rs4588 and rs7041 were combined, they formed six diplotypes with distributions of $47 \%$ GC1S/1S, $25 \%$ GC1S/2, 2 \% GC1F/1 F, 6 \% GC1F/2, $16 \%$ GC1F/1S, and $4 \% G C 2 / 2$. In addition, there were a few undetectable individuals that could have been representing some of the rare diplotypes. Haplotype analysis (combining rs4588 and rs7041) revealed three different haplotypes, corresponding to the three GC protein isoforms GC1S, $\mathrm{GC} 1 F$, and GC2. The distribution of the haplotypes was as follows: $88 \%$ GCIS, $3.7 \%$ GCIF, and $8.5 \%$ GC2. The distribution of the third SNP rs705124 was $61 \%$ genotype $1,34 \%$ genotype 2 , and $5 \%$ genotype 3 . The distributions of the rs4588, rs7041, and rs705124 genotypes were in accordance with Hardy-Weinberg equilibrium ( $p=0.73,0.12,0.80$, respectively). 
Associations of GC genotypes with DBP, 25(OH)D, and PTH concentrations

DBP concentrations in the diplotype and haplotype groups differed from each other significantly $(p=0.039,0.039$, respectively, overall ANCOVA analysis), one of the lowest concentration being in persons with the $G C 2 / 2$ genotype (Fig. 1a). Serum 25(OH)D concentrations differed among the SNP rs4588 genotypes $(p=0.031$, ANCOVA) and also between the six diplotypes of rs 4588 and rs7041 combined (Fig. 1b) ( $p=0.033$, ANCOVA), after adjustment for the covariates S-PTH, vitamin D intake, sunlight exposure, BMI and sex. Also PTH concentrations differed between the diplotypes $(p=0.040)$, adjusted for $25(\mathrm{OH}) \mathrm{D}$ and calcium intake and sex (Fig. 1c).

The difference in S-PTH between the haplotypes was borderline significant $(p=0.078)$, and a linear trend was present $(p=0.044)$ (Table 3). Among the SNP rs705124 genotypes, a difference between PTH concentrations was observed ( $p=0.016$, ANCOVA, data not shown).

\section{Concentrations of free and bioavailable 25(OH)D among genotypes}

Neither the concentration of free nor bioavailable $25(\mathrm{OH}) \mathrm{D}$ concentration differed among the diplo-/haplotypes. However, when the values were genotype-corrected, the highest concentration of free $25(\mathrm{OH}) \mathrm{D}$ was found in diplotype $2 / 2(p<0.001$, ANCOVA $)$ and haplotype $G C 2$ $(p<0.001)$. Similar differences were found among the bioavailable 25(OH)D concentrations $(p<0.001)$ (Fig. 1d, e, Tables 2 and 3). The number of subjects in Tables 2 and 3 are presented as a range because the number varied depending on the value analyzed.

\section{Discussion}

We found differences in the total, genotype-corrected free, and bioavailable $25(\mathrm{OH}) \mathrm{D}$ concentrations and the DBP concentrations among $G C$ genotypes, indicating that the biological response could possibly be modified by the availability of $25(\mathrm{OH}) \mathrm{D}$. Moreover, some genotypes with

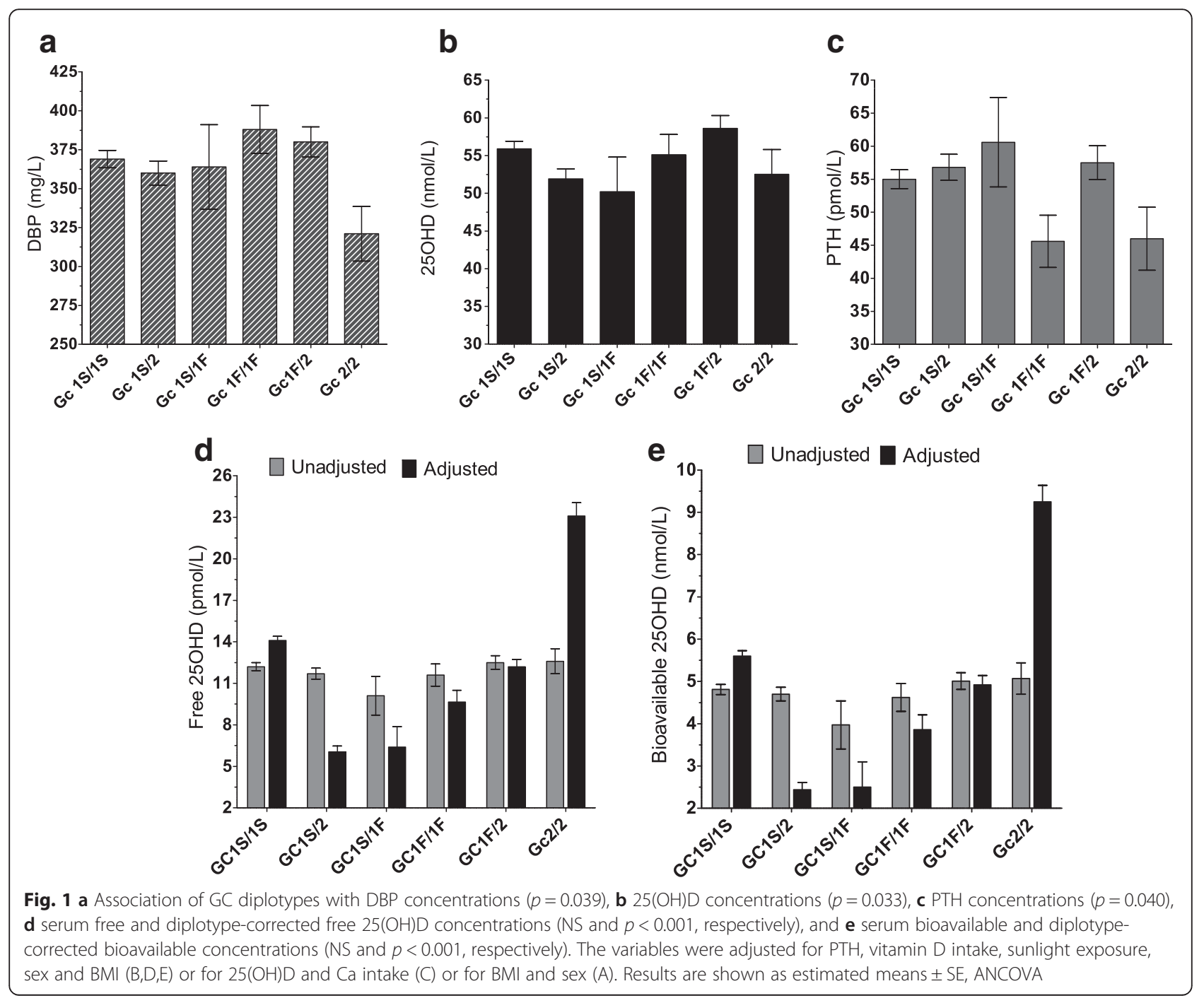


Table 2 Comparison of total 25(OH)D, free and diplotype-corrected free 25(OH)D, and PTH and DBP concentrations among the GC diplotypes

\begin{tabular}{|c|c|c|c|c|c|c|c|c|c|c|c|c|c|c|c|c|c|c|}
\hline \multirow{2}{*}{$\frac{\text { GC diplotypes }}{\text { Dependent variable }}$} & \multicolumn{3}{|c|}{ GC1S/1S } & \multicolumn{3}{|c|}{ GC 1S/2 } & \multicolumn{3}{|c|}{ GC 1S/1 F } & \multicolumn{3}{|c|}{ GC $1 \mathrm{~F} / 1 \mathrm{~F}$} & \multicolumn{3}{|c|}{ GC $1 F / 2$} & \multicolumn{2}{|c|}{ GC 2/2 } & \multirow{2}{*}{$\begin{array}{l}\text { ANCOVA } \\
p \text {-value }\end{array}$} \\
\hline & & & & & & & & & & & & & & & & & & \\
\hline $\mathrm{S}-25(\mathrm{OH}) \mathrm{D}(\mathrm{nmol} / \mathrm{L})$ & $\begin{array}{l}55.9 \\
(280)\end{array}$ & \pm & 0.99 & $\begin{array}{l}51.9 \\
(152)\end{array}$ & \pm & 1.34 & $\begin{array}{l}50.2 \\
(13)\end{array}$ & \pm & 4.6 & $\begin{array}{l}55.1 \\
(38)\end{array}$ & \pm & 2.7 & $\begin{array}{l}58.6 \\
(90)\end{array}$ & \pm & 1.7 & $\begin{array}{l}52.5 \\
(26)\end{array}$ & \pm 3.3 & $0.033^{\mathrm{a}}$ \\
\hline Free 25(OH)D (pmol/L) & $\begin{array}{l}12.2 \\
(236)\end{array}$ & \pm & 0.29 & $\begin{array}{l}11.7 \\
(121)\end{array}$ & \pm & 0.40 & $\begin{array}{l}10.1 \\
(10)\end{array}$ & \pm & 1.40 & $\begin{array}{l}11.6 \\
(31)\end{array}$ & \pm & 0.80 & $\begin{array}{l}12.5 \\
(78)\end{array}$ & \pm & 0.50 & $\begin{array}{l}12.6 \\
(24)\end{array}$ & \pm 0.90 & $0.491^{\mathrm{a}}$ \\
\hline $\begin{array}{l}\text { Diplotype corrected free 25(OH)D } \\
\text { (pmol/L) }^{d}\end{array}$ & $\begin{array}{l}14.1 \\
(236)\end{array}$ & \pm & 0.30 & $\begin{array}{l}6.06 \\
(121)\end{array}$ & \pm & 0.42 & $\begin{array}{l}6.40 \\
(10)\end{array}$ & \pm & 1.47 & $\begin{array}{l}9.65 \\
(31)\end{array}$ & \pm & 0.85 & $\begin{array}{l}12.2 \\
(78)\end{array}$ & \pm & 0.53 & $\begin{array}{l}23.1 \\
(24)\end{array}$ & \pm 0.95 & $<0.001^{a}$ \\
\hline Bioavailable 25(OH)D (nmol/L) & $\begin{array}{l}4.81 \\
(236)\end{array}$ & \pm & 0.12 & $\begin{array}{l}4.70 \\
(121)\end{array}$ & \pm & 0.16 & $\begin{array}{l}3.97 \\
(10)\end{array}$ & \pm & 0.57 & $\begin{array}{l}4.62 \\
(31)\end{array}$ & \pm & 0.33 & $\begin{array}{l}5.01 \\
(78)\end{array}$ & \pm & 0.20 & $\begin{array}{l}5.07 \\
(24)\end{array}$ & \pm 0.37 & $0.469^{\mathrm{a}}$ \\
\hline $\begin{array}{l}\text { Diplotype corrected bioavailable } \\
25(\mathrm{OH}) \mathrm{D}(\mathrm{nmol} / \mathrm{L})^{d}\end{array}$ & $\begin{array}{l}5.60 \\
(235)\end{array}$ & \pm & 0.13 & $\begin{array}{l}2.44 \\
(121)\end{array}$ & \pm & 0.17 & $\begin{array}{l}2.50 \\
(10)\end{array}$ & 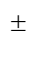 & 0.60 & $\begin{array}{l}3.86 \\
(31)\end{array}$ & \pm & 0.35 & $\begin{array}{l}4.92 \\
(78)\end{array}$ & \pm & 0.22 & $\begin{array}{l}9.25 \\
(24)\end{array}$ & \pm 0.39 & $<0.001^{\mathrm{a}}$ \\
\hline S-DBP (mg/L) & $\begin{array}{l}369 \\
(238)\end{array}$ & \pm & 5.55 & $\begin{array}{l}360 \\
(121)\end{array}$ & \pm & 7.78 & $\begin{array}{l}364 \\
(10)\end{array}$ & \pm & 27.1 & $388(31)$ & \pm & 15.4 & $\begin{array}{l}380 \\
(78)\end{array}$ & \pm & 9.7 & $\begin{array}{l}321 \\
(24)\end{array}$ & \pm 17.5 & $0.039^{b}$ \\
\hline S-PTH (ng/L) & $\begin{array}{l}55.0 \\
(289)\end{array}$ & \pm & 1.44 & $\begin{array}{l}56.8 \\
(157)\end{array}$ & \pm & 1.96 & $\begin{array}{l}60.6 \\
(13)\end{array}$ & \pm & 6.78 & $\begin{array}{l}45.6 \\
(38)\end{array}$ & \pm & 3.96 & $\begin{array}{l}57.5 \\
(92)\end{array}$ & \pm & 2.55 & $\begin{array}{l}46.0 \\
(26)\end{array}$ & \pm 4.79 & $0.040^{c}$ \\
\hline
\end{tabular}

Diplotype means were compared with ANCOVA \pm SE. The values are adjusted estimates from ANCOVA. $\mathrm{N}$ in parenthesis

Significant $\mathrm{p}$-values are indicated in bold

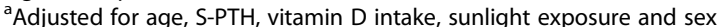

${ }^{\mathrm{b}}$ Adjusted for BMI and sex

'S-25(OH)D, Ca intake

GC diplotype was used as a fixed factor

${ }^{\mathrm{d}}$ Diplotype-corrected free and bioavailable $25(\mathrm{OH}) \mathrm{D}$ values were calculated by placing a diplotype-specific binding coefficient into the free and bioavailable formulae

low 25(OH)D concentrations also had low PTH concentrations, which is contrary to the usual finding for this relationship. Interestingly, the free and bioavailable $25(\mathrm{OH}) \mathrm{D}$ concentrations were high in these groups, which could explain the low PTH concentration.

Previous studies have shown the critical role of $G C$ genotypes and serum GC protein concentration for vitamin D metabolism $[11,12,17,18]$. The $25(\mathrm{OH}) \mathrm{D}$ concentrations have been suggested to differ among DBP phenotypes and genotypes. In this study, we wanted to extend the observations to diplotypes and haplotypes. We discovered a significant difference in $25(\mathrm{OH}) \mathrm{D}$ concentrations among the SNP rs4588 genotypes. A similar difference was also found among the diplotypes when two SNPs, rs4588 and rs7041, were combined. Among the SNP rs4588, the lowest $25(\mathrm{OH}) \mathrm{D}$ concentration was seen in individuals with the GC2/2 genotype and the highest in individuals with $G C 1 / 1$. Within diplotypes, the difference was significant between genotypes $1 S / 2$ and $1 \mathrm{~F} / 2$, the $25(\mathrm{OH}) \mathrm{D}$ concentration being lowest in

Table 3 Comparison of 25(OH)D, free- and diplotype-corrected free $25(\mathrm{OH}) \mathrm{D}$, and DBP and PTH concentrations among the GC haplotypes

\begin{tabular}{|c|c|c|c|c|c|c|c|c|c|c|}
\hline GC haplotype & GC1S & & & GC1F & & & GC2 & & & ANCOVA $p$-value \\
\hline \multicolumn{11}{|l|}{ Dependent variable } \\
\hline $\mathrm{S}-25(\mathrm{OH}) \mathrm{D}(\mathrm{nmol} / \mathrm{L})$ & $57.1(281)$ & \pm & 1.04 & $50.6(13)$ & \pm & 4.9 & $52.7(25)$ & \pm & 3.53 & $0.231^{a}$ \\
\hline Free $25(\mathrm{OH}) \mathrm{D}(\mathrm{pmol} / \mathrm{L})$ & $12.5(237)$ & \pm & 0.30 & $10.1(10)$ & \pm & 1.46 & $12.6(23)$ & \pm & 0.97 & $0.280^{a}$ \\
\hline Diplotype corrected free $25(\mathrm{OH}) \mathrm{D}(\mathrm{pmol} / \mathrm{L})^{\mathrm{e}}$ & $14.2(237)$ & \pm & 0.35 & $6.30(10)$ & \pm & 1.70 & $22.8(23)$ & \pm & 1.12 & $<0.001^{a}$ \\
\hline Bioavailable 25(OH)D (nmol/L) & $4.92(237)$ & \pm & 0.12 & $3.98(10)$ & \pm & 0.59 & $5.01(23)$ & \pm & 0.39 & $0.261^{\mathrm{a}}$ \\
\hline Diplotype corrected bioavailable 25(OH)D (nmol/L) ${ }^{e}$ & $5.61(237)$ & \pm & 0.14 & $2.47(10)$ & \pm & 0.68 & $9.15(23)$ & \pm & 0.45 & $<0.001^{\mathrm{a}}$ \\
\hline $\mathrm{S}-\mathrm{DBP}(\mathrm{mg} / \mathrm{L})$ & $369(240)$ & \pm & 5.60 & $364(10)$ & \pm & 27.4 & $320(23)$ & \pm & 18.1 & $0.039^{b}$ \\
\hline S-PTH (ng/L) & $54.5(283)$ & \pm & 1.39 & $60.7(13)$ & \pm & 6.52 & $44.7(25)$ & \pm & 4.70 & $0.078 c^{d}$ \\
\hline
\end{tabular}

Haplotype means were compared with ANCOVA \pm SE. The values are adjusted estimates from ANCOVA. N in parenthesis

Significant $p$-values are indicated in bold

${ }^{a}$ Adjusted for age, S-PTH, vitamin D intake, sunlight exposure and sex

${ }^{\mathrm{b}}$ Adjusted for BMI and sex

${ }^{\mathrm{S}} \mathrm{S}-25(\mathrm{OH}) \mathrm{D}, \mathrm{Ca}$ intake

${ }^{d}$ a linear trend, $p=0.044$

GC haplotype was used as a fixed factor

eHaplotype-corrected free and bioavailable $25(\mathrm{OH}) \mathrm{D}$ values were calculated by placing a haplotype-specific binding coefficient into the free and bioavailable formulae 
genotype $1 \mathrm{~S} / 1 \mathrm{~F}$ and highest in $1 \mathrm{~F} / 2$. Our results are in line with earlier studies [18-21]. Most of the studies have focused on the two common SNPs rs4588 and rs7041, but they are seldom used in combination to form diplotypes.

In this study, the DBP concentrations varied significantly among the $G C$ genotypes. The lowest DBP concentration was found in $G C 2 / 2$ and the highest in $G C 1 / 1$. In diplotypes, the highest concentration was found in $G C 1 F /$ $1 F$ and the lowest in $G C 2 / 2$. A significant difference in DBP concentration emerged between $G C 1 F / 2$ and $G C 2 / 2$. Also haplotype-corrected DBP values differed; the highest value was observed in GC1S and the lowest in GC2. Variation in DBP concentrations based on DBP genotypes has been reported also in previous studies, but the results have not been consistent $[11,18,21]$. Powe et al. [11] reported that the T-allele at rs7041 was associated with decreased concentrations of DBP, and allele A at rs4588 was associated with higher DBP, after accounting for rs7041. In a study conducted with African American and Caucasian American subjects, GC1S homozygotes had the highest DBP concentration, $G C 2$ had an intermediate concentration, and GC1F had the lowest concentration [18]. Similar to our results, a Danish study observed that GC2 homozygotes generally had lower DBP concentrations than the other genotypes [21].

However, criticism has been directed at some of the measurement protocols used by earlier studies for determining the DBP concentration. It has been suggested that studies based on monoclonal antibodies $[11,18]$ may be inaccurate because the assay might not have equal affinity for all genotypes. The use of polyclonal antibodies instead has been proposed [22].

Based on the free hormone hypothesis, the free fractions could correlate better with biological actions of vitamin D than the total $25(\mathrm{OH}) \mathrm{D}$ [9]. In order to test the free and the bioavailable hypotheses, we calculated the concentrations of unbound "free" $25(\mathrm{OH}) \mathrm{D}$ and bioavailable 25(OH)D. A Norwegian study found that adjusting for DBP phenotype-specific (SNPs rs4588 and rs7041 combined) binding coefficients affected the calculated free and bioavailable concentrations by up to $37.5 \%$ [10]. Thus, additional genotype adjustment was made for diplotypeand haplotype-specific binding coefficients. In our study, serum free or bioavailable $25(\mathrm{OH}) \mathrm{D}$ concentrations did not differ significantly between the genotypes. However, after adjustment for diplotype-specific binding coefficients a significant difference emerged in free and bioavailable values among the haplotypes and diplotypes. The highest concentrations of free and bioavailable 25(OH)D were found in GC 2/2 and the lowest in haplotype GC1F and diplotypes $G C 1 S / 2, G C 1 S / 2$, and $1 S / 1$ F. Powe et al. [11] stated that genetic polymorphism explained almost $10 \%$ of the variation in $25(\mathrm{OH}) \mathrm{D}$ levels. In their study, the T- allele at rs7041 was associated with decreased levels of vitamin D-binding protein in both black and white Americans. In white individuals, the A-allele at rs4588 was associated with decreased levels of total $25(\mathrm{OH}) \mathrm{D}$.

An inverse association between 25(OH)D and PTH has been found in numerous studies. PTH has therefore been suggested to be used as a health outcome reference for optimal vitamin D status. However, the cut-off values for PTH and 25(OH)D differ considerably among studies, making this very difficult. Moreover, large variation exists in PTH at specific $25(\mathrm{OH}) \mathrm{D}$ concentrations [13]. In our previous study in Finnish children and adolescents, we observed that GC2 phenotype was associated with the lowest $25(\mathrm{OH}) \mathrm{D}$ concentrations and that there was an inverse association between $25(\mathrm{OH}) \mathrm{D}$ and PTH within the genotypes [23]. Interestingly, the $G C 2 / 2$ genotype, which had the lowest $25(\mathrm{OH}) \mathrm{D}$, also had the lowest PTH concentration, which is contrary to the association in general. Here, we found differences in PTH concentrations among the diplotypes and a similar linear trend in haplotypes. GC2/2, with the second lowest $25(\mathrm{OH}) \mathrm{D}$ among diplotypes, also had the lowest PTH.

In accord with our finding, a Danish study observed that rs4588-AA carriers had the lowest prevalence of $25(\mathrm{OH}) \mathrm{D}>50 \mathrm{nmol} / \mathrm{L}$ in a vitamin $\mathrm{D}$ fortification group, but in the control group the SNP rs4588 carriers had the lowest prevalence of low vitamin D status. They state that this may suggest that rs4588 carriers have low, yet stable $25(\mathrm{OH}) \mathrm{D}$ concentrations. The rs4588-AA genotype had also lower PTH levels and $25(\mathrm{OH}) \mathrm{D}$ concentrations relative to rs4588-CC or rs4588-CA carriers [20]. In comparison, the genetic variance in $G C$ significantly contributed to circulating DBP as well as to $25(\mathrm{OH}) \mathrm{D}$ in a study in North American children [24]. However, in that study both total and free $25(\mathrm{OH}) \mathrm{D}$ correlated inversely with $\mathrm{PTH}$, and this correlation was independent of DBP genotype. Interestingly, we also noted a difference in PTH concentrations among SNP rs705124, which has not been reported in earlier studies. Thus, our results emphasize the importance of the genetic variation in DBP in vitamin D and mineral metabolism.

In addition to renal production of $1,25(\mathrm{OH})_{2} \mathrm{D}_{3}$, there is local production in non-renal tissues. Based on our previous findings and the results in this paper, we hypothesize that free $25(\mathrm{OH}) \mathrm{D}$ may enter the parathyroid glands and might be converted locally to $1,25(\mathrm{OH})_{2} \mathrm{D}_{3}$ with the help of cytochrome p450 27B1 enzyme (CYP27B1) in the cell. The higher amount of $1,25(\mathrm{OH})_{2} \mathrm{D}_{3}$ could suppress the production of $\mathrm{PTH}$ and explain the lower concentration of PTH with the GC2/2 genotype. Our results support those of Ritter et al. [25], who demonstrated the presence of 25(OH)D 1-alpha-hydroxylase (1alpha-OHase) in cultured bovine parathyroid cells and showed that the enzyme was functionally active, converting $25(\mathrm{OH}) \mathrm{D}$ to 1 - 
hydroxylated metabolites and inducing the major enzyme involved in the degradation of calcitriol, 25(OH)D 24hydroxylase (24-OHase, CYP24A1). This together with the fact that vitamin D receptor (VDR) was expressed in the cells suggests an autocrine/paracrine function for locally produced $1,25(\mathrm{OH})_{2} \mathrm{D}_{3}$. They showed that $25(\mathrm{OH}) \mathrm{D}$ suppressed the production of PTH without the involvement of conversion to $1,25(\mathrm{OH})_{2} \mathrm{D}_{3}$, but possibly by interaction with VDR. The experiments were done in serum-free medium, indicating that no DBP was needed for the internalization and that the effects could be due to free $25(\mathrm{OH}) \mathrm{D}$. Therefore, local production of 1alphaOHase suggests an autocrine/paracrine role in regulating parathyroid function and may mediate, in part, the suppression of PTH by calcium and FGF-23 [25].

A Canadian study concluded that the biological effect of vitamin $\mathrm{D}$ on PTH concentration is mainly independent of DBP concentrations [12]. Another North-American study reported that genetic variance in $G C$ significantly contributed to circulating DBP as well as to $25(\mathrm{OH}) \mathrm{D}$ [24]. However, both total and free 25(OH)D were correlated inversely with $\mathrm{PTH}$, and this correlation was independent of DBP genotype. This reinforces our hypothesis that free and bioavailable $25(\mathrm{OH}) \mathrm{D}$ may be good biomarkers of vitamin $\mathrm{D}$ status and action in cells than serum 25(OH)D per se.

One of the limitations of this study is that it was not designed to demonstrate a difference in the concentration of $25(\mathrm{OH}) \mathrm{D}, \mathrm{DPB}$, or PTH in the different genotypes. The study derives from a larger study focusing on phosphorus intake and bone outcomes. The sample size was calculated to find a $4 \%$ difference (standard deviation, SD-0.050 g/cm2) in distal radius bone mineral density between the highest and lowest phosphorus intake tertiles.

Other limitation of this study is that the affinity constants of DBP by Arnauld et al. [6] are derived by experimental evidence from one individual's human serum sample. It has not been investigated whether posttranslational modification of Gc may influence affinity for vitamin D metabolites. In addition, the Gc affinity constant for 25(OH)D3 in published literature ranges by several orders of magnitude from $1.9 \times 10-10$ to 1.5 to $10-8$ [1]. It is also known that Gc protein circulates several fold above $25(\mathrm{OH}) \mathrm{D}$ concentrations, with only approximately $5 \%$ of circulating Gc protein occupied by vitamin D metabolites.

As we do not have the full protein sequence, we cannot be certain whether we have some of the other Gcisoforms. According to Arnaud's analysis, binding affinity of these more rare isoforms may vary as much as 12 fold. Nevertheless, the other isoforms are quite rare. Arnauld's affinity constants are estimated for 25(OH)D3 and not for $25(\mathrm{OH}) \mathrm{D} 2$ but this is not a problem for the interpretation of the results as vitamin $\mathrm{D}_{2}$ is not found in foods and only in a few supplements in Finland as food is fortified with vitamin D3 and most of the supplements are vitamin D3.

\section{Conclusions}

Our findings indicate that genetic polymorphisms of DBP and free and bioavailable concentrations of $25(\mathrm{OH}) \mathrm{D}$ may be of relevance when vitamin $\mathrm{D}$ status and vitamin $\mathrm{D}$ metabolism are evaluated. Important findings were the relationships between PTH and free and bioavailable $25(\mathrm{OH}) \mathrm{D}$ and genetic variation of $\mathrm{DBP}$.

\section{Additional files}

Additional file 1: Table S1. Characteristics of subjects according to GC genotypes. (DOCX $16 \mathrm{~kb}$ )

Additional file 2: Table S2. Characteristics of the subjects stratified by sex. (DOCX $13 \mathrm{~kb})$

\section{Abbreviations \\ $1,25(\mathrm{OH})_{2} \mathrm{D}_{3}, 1,25$ dihydroxyvitamin $\mathrm{D} ; 25(\mathrm{OH}) \mathrm{D}, 25$-hydroxyvitamin $\mathrm{D}$; ANCOVA, analysis of covariance; BMI, body mass index; Ca, calcium; CEU population, Northern Europeans from Utah; DBP, Vitamin D binding protein; ELISA assay, enzyme-linked immunosorbent assay; FFQ, Food frequency questionnaire; FGF23, Fibroblast growth factor; GC, group specific component; KALB, affinity constant for $25(\mathrm{OH}) \mathrm{D}$ with albumin; KDBP, affinity constant for $25(\mathrm{OH})$ D with vitamin D binding protein; PHOMl- study, Dietary phosphorus and health outcomes study; PTH, parathyroid hormone; SNP, Single nucleotide polymorphism; UVB, Ultraviolet B; VDR, vitamin D receptor}

\section{Acknowledgements}

We thank the participants of the PHOMI study. We also thank technician Anu Heiman-Lindh for performing the DBP concentration measurements as well as assisting in other laboratory analyses.

\section{Funding}

This work was supported by the Academy of Finland (grant number 127536), the Doctoral School for Applied Biosciences (ABS), the University of Helsinki Future Fund, the Finnish Cultural Foundation, Alfred Kordelin Foundation and the Liv och Hälsa Foundation.

\section{Availability of data and materials \\ The unidentified data from this study is available through corresponding author for any interested party with appropriate rationale.}

\section{Authors' contributions}

Study design: ES, MP, STI, VK, HK, MK, OM, CLA. Study conduct: ES, MP, STI, VK, HK, MK, CLA. Data collection: ES, MP, STI, VK, HK, MK, CLA. Data analysis: ES and MP. Data interpretation: ES, MP, and CLA. Drafting the manuscript: ES with the help of MP and CLA. Revising manuscript content: ES, MP, STI, VK, HK, MK, OM and CLA. Approving final version of the manuscript: MP, ES, STI, VK, HK, MK, OM and CLA. ES, MP and CLA take responsibility for the integrity of the data analysis. All authors read and approved the final manuscript.

\section{Competing interests}

The authors declare that they have no competing interests.

\section{Consent for publication}

Not Applicable.

\section{Ethics approval and consent to participate}

All subjects gave their informed consent to the procedures, which were in accord with the Helsinki Declaration. The study protocol was approved by the Helsinki Uusimaa Hospital District Ethics Committees. 


\section{Author details}

Calcium Research Unit, Department of Food and Environmental Sciences, University of Helsinki, P.O. Box 66Fl-00014 Helsinki, Finland. ${ }^{2}$ Folkhälsan Institute of Genetics, Folkhälsan Research Center, Helsinki, Finland. ${ }^{3}$ Children's Hospital, Helsinki University Central Hospital and University of Helsinki, Helsinki, Finland.

Received: 10 February 2016 Accepted: 13 July 2016

Published online: 22 July 2016

\section{References}

1. Bikle DD, Gee E, Halloran B, Kowalski MA, Ryzen E, Haddad JG. Assessment of the free fraction of 25-hydroxyvitamin $D$ in serum and its regulation by albumin and the vitamin D-binding protein. J Clin Endocrinol Metab. 1986:63:954-9.

2. Yamamoto N, Kumashiro R. Conversion of vitamin D3 binding protein (group-specific component) to a macrophage activating factor by the stepwise action of beta-galactosidase of B cells and sialidase of T cells. J Immunol. 1993;151:2794-802.

3. Yamamoto N, Naraparaju VR, Orchard PJ. Defective lymphocyte glycosidases in the macrophage activation cascade of juvenile osteopetrosis. Blood. 1996;88:1473-8.

4. Schneider GB, Benis KA, Flay NW, Ireland RA, Popoff SN. Effects of vitamin D binding protein-macrophage activating factor (DBP-MAF) infusion on bone resorption in two osteopetrotic mutations. Bone. 1995;16:657-62.

5. Braun A, Bichlmaier R, Cleve H. Molecular analysis of the gene for the human vitamin-D-binding protein (group-specific component): allelic differences of the common genetic GC types. Hum Genet. 1992;89:401-6.

6. Arnaud J, Constans J. Affinity differences for vitamin D metabolites associated with the genetic isoforms of the human serum carrier protein (DBP). Hum Genet. 1993;92:183-8.

7. Gozdzik A, Zhu J, Wong BY, Fu L, Cole DE, Parra EJ. Association of vitamin D binding protein (VDBP) polymorphisms and serum 25(OH)D concentrations in a sample of young Canadian adults of different ancestry. J Steroid Biochem Mol Biol. 2011;127:405-12.

8. Mendel CM. The free hormone hypothesis: a physiologically based mathematical model. Endocr Rev. 1989:10:232-74.

9. Chun RF, Lauridsen AL, Suon $L$, et al. Vitamin D-binding protein directs monocyte responses to 25-hydroxy- and 1,25-dihydroxyvitamin D. J Clin Endocrinol Metab. 2010;95:3368-76.

10. Johnsen MS, Grimnes G, Figenschau Y, et al. Serum free and bio-available 25-hydroxyvitamin D correlate better with bone density than serum total 25 hydroxyvitamin D. Scand J Clin Lab Invest. 2014;74:177-83.

11. Powe CE, Evans MK, Wenger J, et al. Vitamin D-binding protein and vitamin D status of black Americans and white Americans. N Engl J Med. 2013;369:1991-2000.

12. Dastani Z, Li R, Richards B. Genetic Regulation of Vitamin D Levels. Calcif Tissue Int. 2013:92:106-17.

13. Sai AJ, Walters RW, Fang X, Gallagher JC. J Relationship between vitamin $D$, parathyroid hormone, and bone health. Clin Endocrinol Metab. 2011;96:E436-46.

14. Itkonen ST, Karp HJ, Kemi VE, et al. Associations among total and food additive phosphorus intake and carotid intima-media thickness-a crosssectional study in a middle-aged population in Southern Finland. Nutr J. 2013;12:94.

15. Outila TA, Kärkkäinen MU, Lamberg-Allardt CJ. Vitamin D status affects serum parathyroid hormone concentrations during winter in female adolescents: associations with forearm bone mineral density. Am J Clin Nutr. 2001:74:206-10.

16. Nordic Council of Ministers. Nordic Nutrition Recommendations 2012. Copenhagen: Nord; 2013. 009.

17. Lauridsen AL, Vestergaard P, Hermann AP, et al. Plasma concentrations of 25-hydroxy-vitamin $D$ and 1,25-dihydroxy-vitamin $D$ are related to the phenotype of Gc (vitamin D-binding protein): a cross-sectional study on 595 early postmenopausal women. Calcif Tissue Int. 2005;77:15-22.

18. Wilson RT, Bortner Jr J, Roff A, et al. Genetic and environmental influences on plasma vitamin D binding protein concentrations. Transl Res. 2015;165:667-76.

19. Sinotte M, Diorio C, Bérubé S, Pollak M, Brisson J. Genetic polymorphisms of the vitamin D binding protein and plasma concentrations of 25-hydroxyvitamin D in premenopausal women. Am J Clin Nutr. 2009;89:634-40.
20. Nissen J, Rasmussen LB, Ravn-Haren G, et al. Common variants in CYP2R1 and GC genes predict vitamin D concentrations in healthy Danish children and adults. PLoS One. 2014;9:e89907.

21. Lauridsen $A L$, Vestergaard $P$, Nexo $E$. Mean serum concentration of vitamin D-binding protein (Gc globulin) is related to the Gc phenotype in women. Clin Chem. 2001:47:753-6.

22. Bouillon $\mathrm{R}$, Jones $\mathrm{K}$, Schoenmakers I. Vitamin D-binding protein and vitamin D in blacks and whites. N Engl J Med. 2014;370:879.

23. Pekkinen M, Saarnio E, Viljakainen $H T$, et al. Vitamin D binding protein genotype is associated with serum 25-hydroxyvitamin D and PTH concentrations, as well as bone health in children and adolescents in Finland. PLoS One. 2014;30(9):e87292. doi:10.1371/journal.pone.0087292.

24. Carpenter TO, Zhang JH, Parra $\mathrm{E}$, et al. Vitamin D binding protein is a key determinant of 25-hydroxyvitamin D levels in infants and toddlers. J Bone Miner Res. 2013:28:213-21.

25. Ritter CS, Haughey BH, Armbrecht HJ, Brown AJ. Distribution and regulation of the 25-hydroxyvitamin D3 1a-hydroxylase in human parathyroid glands. J Steroid Biochem Mol Biol. 2012;130:73-80.

\section{Submit your next manuscript to BioMed Central and we will help you at every step:}

- We accept pre-submission inquiries

- Our selector tool helps you to find the most relevant journal

- We provide round the clock customer support

- Convenient online submission

- Thorough peer review

- Inclusion in PubMed and all major indexing services

- Maximum visibility for your research

Submit your manuscript at www.biomedcentral.com/submit
) Biomed Central 